\title{
The Israeli-Palestinian Conflict and International Relations
}

\author{
Lin, Pengzhe* \\ Cranbrook Schools, $M I$ \\ *Corresponding Author: Lin, Pengzhe, Cranbrook Schools, MI
}

\section{INTRODUCTION}

A twelve-year-old boy who suffered a fatal shot is hiding against a wall from the gunfight with his injured father; the dead body of an Israeli soldier is thrown out of the police station and is humiliated and paraded by the mob; Youths used their body as suicide bombings to reach justice; people lived in fear as violence and protests happened everywhere (Harms, pg171). These all happened since September 28, 2000, the day when all hatred and conflicts gathered and exploded as Ariel Sharon, the leader of the Israeli Likud party showed up at the Temple Mount and Haram al-Sharif in Jerusalem. This dramatic and debatable visit to the Holy Land triggered what is known as the second Intifada, or the Al Aqsa Intifada.

While Sharon's actions on the Temple Mount certain sparked the Second Intifada, the present paper will argue that there are three deeper causes that stood behind the conflict. This passage will demonstrate the three main causes of The Second Intifada: continued occupation of the West Bank, failures of the past peace attempt to resolve the occupation and the increasing number of settlements, and the problem of how to share religious space in the Old City of Jerusalem. After giving a brief history of the background of the Intifada, the following paper will demonstrate this argument.

\section{THE BACKGROUND OF THE SECOND INTIFADA}

The Leader of the Israeli Likud Party, Ariel Sharon, took a visit to the Temple Mount/ Haram alSharif in Jerusalem on September $8^{\text {th }}, 2000$. A visit to the heart of the Palestinian culture by a leader known to be against transferring land to Palestinian control who is accompanied by a thousand police officers on the fifth anniversary of the signing of Oslo II brought out considerable controversy. (Harms, 170). Demonstrators who blocked his access to the sites are attacked by rubber-coated bullets and tear gas. As anger reached its maximum, the opportunity for compromise had closed. The disillusionment of the younger Palestinian generation with the failure in settlement of the Oslo peace process and the disgrace of unfair occupation could no longer be kept quiet. (Bunton, 222). The Second Intifada took place the next day as Palestinians threw stones at Israel Defense Forces(IDF) and praying Jews while the IDF used real gunfire, causing 4 death cases of Palestinians (Harms, 170). While the UN and Human Rights Organizations condemned IDF's use of live ammunition, the tone for the second uprising is set up by violence.

Compared to the 1987 intifada, more high-tech implements are utilized this time, including a roadside bomb from Palestinians and tanks and helicopters from IDF (Harms, 171). The protests and violence weren't settled by any attempts or statements by Barak and Arafat, statesman from Israel and Palestine respectively. Two weeks after the uprising, Clinton set up a summit and an oral arrangement was reached with both sides in attempts to find a truce. Clinton tried to be the mediator that guided both sides to peace, however, anger and frustration ended the meeting (Bunton, 219). There were no implementations followed and more ineffective and reluctant meetings were unable to reach peace. More attempts to secure international involvement were also unsuccessful. The US president election in November 2000 created a temporary distraction. In the end, George W. Bush became the 43rd President of the United States (Harms, 172). Between the two-month gap until Bush's assumption of office, Clinton made a final endeavor, the "Clinton Plan" which is a delivered speech about separating lands, making clear of religious places, and an undetermined refugee plan, but the plan differed very little from previously discussed during Camp David II. Eventually, negotiations continued as the Taba Statement during January 21-27 2001, nevertheless, the ineffective declarations of "spirit of hope and 
mutual achievement" did not help the situation. In the end, both sides claimed they had never been so close to a resolution of the outstanding issues (Bunton, 222). Little hope of improvement deteriorated the conflict while Bush's administration decided to be more distant to the conflict (Harms, 172).

In February 2001, under the attack from Palestinians, traumas to the political left enabled Sharon to defeat Barak and become prime minister in the election (Bunton, 225). Sharon put more distance between his government and continued negotiations, showing his career will continue to be against transferring territory to the Palestinians or the return of refugees. (Harms, 173). Palestinians were clear of the consequences as Sharon put in more power, on the other hand, Bush showed his support to Sharon by blaming Arafat solely for terrorism. As Sharon and Bush had more gatherings, Arafat was never invited from both of them: until terror and violence ceased, nothing. Arafat did little to control the violence under this volatile environment. Without a leader, Palestinian Security Force employed light automatic weapons while suicide bombing campaigns are directed to target Israeli civilians.

These new circumstances caused suicide bombings and religious and secular Palestinian groups' protests to increase under Sharon as the power among Palestinans had become more fragmented. (Bunton, 225). The IDF put in more responses such as "targeted killings," "house demolition," and "assassinations." Anyone who is suspected to join in terrorist activity will face danger (Harms, 174). Israel warranted their massive military force by the concern of security. They accused Arafat's engagement in violence as a strategy to pursue political objectives (Bunton, 226). The relationship between Sharon and Bush turned weak as the unprecedented attack on September 11. 2001, when terrorists hijacked aircraft and flew into the World Trade Center towers and the Pentagon(Harms, 175). As Bush declared the "war on terrorism," in which he judges countries either "with us or against us." He concluded to leave Israel alone to deal with terrorism and the IDF upgraded their responses to the Intifada. (Bunton, 227). In late April 2002, the IDF reentered the territories they once withdrew after Oslo and destroyed many infrastructures of the Palestinian Authority. Although the UN Security Council called for the immediate end of violence, Israel continued its reoccupation in the West Bank. By the summer of 2003, around 2400 Palestinians and 800 Israelis had lost their lives. (Bunton, 224). More than 2800 refugee housings were damaged and 878 homes were demolished, leaving more than 17,000 people homeless (Harms, 175).

As the world is greatly affected by the events of $9 / 11$, Sharon started a unilateral approach which is now known as the "disengagement" in order to separate themselves from Palestinians. (Bunton, pg227). In June 2002, Israel began its construction of the barrier or the wall. As it first started at the north end of the West Bank, it gradually traced the border to the south. However, these barriers were mostly within the Palestinian boundary and continually snaked deep into the West Bank, devouring more portions of land from the Palestinians. Also, the composition of the walls varied from place to place: chain-link, razor wire, or concrete wall. 253 barriers which projected 436 miles were completed in January 2007 (Harms, 176).

Israel claimed the "Security Fence" is used to protect their citizens from terrorists and it enables the IDF to prevent attacks and violence. As expected, Israel received condemnation from the world, questioning the legality of the fence being built inside the Palestinian territory. The International Court of Justice ruled the construction of barriers is equivalent to annexation of incorporation of new territory into their domain. (Harms, 178). The barriers still remained a controversial problem as Israelis supported the construction as high as 80 percent, while Palestinians feared the political fluctuation and daily life being affected. In early 2006, in an interview with the Israeli prime minister, Ehud Olmert, it is clear that the new boarders and fences will be a way for Israel to be separated from the Palestinian population. (Harms, 178).

In addition, the second feature of the plan of disengagement involves the removal of 8,000 Jewish settlers from Gaza Strip, a place where 1.3 million Palestinians live. This act provided deeper cover for Israeli control over the West Bank. (Bunton, 228). Currently, if all the walls become permanent, Israel's annexation of approximately 10 percent of the West Bank, including all the settlements, farmland, and resources. (Harms, 178). Sharon's unilateral disengagement was an alternative to negotiation in the first place. Arafat had been put to blame for violence and an impossible partner in peace. Sharon had marginalized Arafat internationally by labeling him as an international enemy. (Bunton, 229). 


\subsection{Analysis: The Causes of the Second Intifada}

Having given an overview of the background and history of the Second Intifada the following section analyzes some of the main causes behind the conflict. One of the main causes of the Second Intifada has been the continued occupation of the Palestinian territories. The numerous attempts by the UN to get the Israelis to withdraw from the territories demonstrates that the occupation stands at the heart of the conflict. However, Israelis had always found omissions or loopholes to continue to occupy some territory and settlement. After the Oslo process divided the West Bank, Israeli control was still dominant in in Palestinian areas (Bunton, pg175). Also, Israeli settlements had notbeen clearly forbidden in Oslo, causing rapid growth of settlers by at least 117 percent in Gaza and 46 percent in the West Bank (Pressman, 120). These two places were all considered as controversial areas. By encouraging settlements and gaining larger populations, Israel had the opportunities to get more land through building up their city at the site. At the same time, the Israelis hoped to reduce contact with the Palestinians as their drivers delivered to or from the settlement, so they set up many bypass roads (Pressman, 121). These roads further devastated Palestinians by cutting the Palestinian State into multiple fragments. Palestinians were hoping for a different life after the Oslo agreement, however, nothing had changed. Their expectation failed and turned into rage.

In order to understand the background of the failures it is necessary to step back to the aftermath of the Six Day War in 1967. The Six Day War was the war that involved Israel, Egypt, Syria, and Jordan in 1967. During the six days, Israel successfully took possession of the West Bank, the Gaza Strip, the Golan Heights, and the Sinai Peninsula through military force. The United Nations reacted quickly by unanimously adopting UN Resolution 242. The ultimate goal of the resolution was to emphasize "the inadmissibility of the acquisition of territory by war" and require "Withdrawal of Israeli armed forces from territories occupied in the recent conflict". Although the intention was to cease all hostilities and return all of the territories to the pre-1967 status, different interpretations toward the resolution diverted what the UN intended. While the Arabs claimed to want Israel to withdraw from all occupied territories, Israel argued that since the word "the" was missing before the word "territories" in the clause of the resolution that implied that they could hold on to some territories (Bunton, pg175). The vague wording meant that the controversy over the return of occupied territories was not achieved.

The failure of Resolution 242 to settle the question of the occupied territories resulted in other attempts to achieve peace between Israel and the Palestinians. The Oslo Accords were a milestone in the hope for peace between the Israelis and the Palestinians in the Middle East. The first stage of the Oslo Accords, which was Oslo Negotiation I, built up a starting point by letting both sides acknowledge each other in 1993. The Palestinian Liberation Organization (PLO) agreed to recognize Israel as a state, while Israel acknowledged the PLO as the representative of Palestinian people. Oslo I also set up the agenda for Oslo II, which involved discussion for the future. Palestine was given the authority to oversee the West Bank and Gaza, while the West Bank was divided into three zones into different zones. Zone A, which is 3 percent of the West Bank and contain six main cities is under Palestinian control. Zone B is 24 percent of the West Bank with 450 small towns and villages and this area is under joint Palestinian-Israeli control. Zone $\mathrm{C}$ is 74 percent of the West Bank under Israeli control (pending "permanent status negotiations") and it contains Jewish settlements, Jerusalem, military bases, and state lands. The accord also suggested that the territory in Zone $\mathrm{C}$ would slowly transfer to Palestinian control. Palestine strongly believed the literal meaning, however, whereas Israel interpreted it differently because of the vague language. In 1998, Palestinians accused Israel of not following through and withdrawing from Gaza, while at the same time speeding up their construction of settlements in the West Bank. As a result, the peace created by Oslo was short-lived and ultimately led to further violence and tension and eventually the outbreak of the Second Intifada.

\subsection{Analysis \#2: The Question of the Settlements}

Before the Six-Day war of 1967, the West Bank was the home for about a million Palestinians who had lived under Jordan's control. Nevertheless, under the Oslo Accords, roughly 670 Palestinian homes were devastated from 1993 to 1998. (Pressman, 121). Israeli civilians initially moved to Jewish communities, also known as settlements, in the West bank, then to Hebron, a city with important religious sites for Judaism. After that point, numerous Jewish settlements were started inside the West 
Bank as Israel confiscated about 51,000 acres of land from the West Bank.(Pressman, 121). The main reason why Jewish settlement suddenly arose was the economic opportunities in the nature of the West Bank because the Israeli government encouraged people to move there to have a lower life cost than living inside Israel.It is also believed that some religious followers wanted to reclaim their ancient homeland. For example, Jews consider the West Bank the ancient territories of some of their ancestors, the ancient Israelite tribes. For this reason, the settlers refer to the West Bank by their ancient names Judea and Samaria, both of which are names from the Hebrew Bible.

The Jewish settlements also had security forces as part of their infrastructure because they claimed that they had the right to protect themselves. This argument, however, was later interpreted to be adding another reason to occupy the West Bank permanently with military preparation. Zone C, which was previously mentioned in Oslo, was where most of the settlements are located because of the zone's urban, agricultural and economic potential. About $60 \%$ of the Zone $\mathrm{C}$ has been blocked from Palestiniansby making these lands state-land, distributing these lands to settlements, or introducing prohibition in the boundaries of Israeli land and the West Bank. In the remaining $40 \%$ of zone $\mathrm{C}$, Palestinian construction projects or building permits haveseldom been approved by the Israeli restriction. The Civil Administration did draft a plan to solve this problem, however, the plan only covered only about $1 \%$ of the total area of Zone C.

Since efforts to change the situation ended in futility and Palestinians still needed to support their livelihood, they had no choice but to build their houses or businesses without a permit. Nevertheless, they were forced to face threats that the state of Israel could tear down their houses or businesses any day. The Israeli restrictions extended beyond Zone $\mathrm{C}$ and reached into Zones A and $\mathrm{B}$. As the need for more land increased swiftly and the Palestinian populationdoubled in the year, the zone A and B's resources are nearly exhausted, requiring people to utilizeareas with economic potential for residential needs. Palestinian authorities cannot bring public supplies like schools, hospitals, or recreations because of the shortage of construction land and materials.

In addition, the rise of settlements also gave Israel more incentive to control the borders, including international borders, borders with Israeli authority, and even Palestinian borders between town to town. Israeli control of the borders means they can close or open any borders at any time. They disrupted trade, taxation, travel, postal services, etc. (Pressman, 121), which further complicated the Palestinian economy and development and isolated each Palestinian community from other communities.

Settlements building and transportation stimulated Israel to develop bypass roads in the West Bank. These bypass roads were used for Israeli drivers to drive from settlement to settlement or to Israeli authorities. Although the intention for these roads were to avoid interaction with Palestinians in order to avoid conflict, these roads further cut Palestinian cities and towns into pieces.

\subsection{Analysis \#3: The Role Of Jerusalem In The Second Intifada}

Last but not least, Sharon's visit to the Temple Mount or Haramesh-Sharif may have been the catalyst for the Second Intifada, but it was not necessarily the larger cause. Before 1967, Jerusalem was divided into West and East sections that were controlled by Israel and Jordan, respectively. This was because after the war of 1948 when the State of Israel was created the city of Jerusalem would be divided at what is called the Green Line, the partition between Israel and her neighbors. After the SixDay War, however, Israel captured East Jerusalem which meant that the entire city would fail under the country's control. Although in 1980 East Jerusalem was considered illegal under Israelis control, Israel determined that Jerusalem cannot be divided, while Palestinians maintained hope to build a capital for their state in the eastern part of the city. However, the significance of East Jerusalem was that it contained some of the holiest sites for Islam, Judaism, and Christianity, like the Temple Mount. As a result, in order to understand why the Sharon's actions on the Temple Mount would have been viewed as especially provocative it becomes necessary to examine the history of sacred space in Jerusalem.

Sharon's visit revolved around the sacred area to Jews and Muslims known as the Temple Mount or Haram esh-Sharif, which is located just above the Western Wall plaza. The Haram/Temple Mount mainly consists of two parts that make the area a sanctuary for Muslims: the al-Aqsa Mosque and the Dome of the Rock. This part of Jerusalem lies in the Old City, which before 1967 had not been part of 
the State of Israel. Rather, the Old City of Jerusalem stood right between the border of Israel and Palestine, making both countries claim their rights to put this area into their state. Haram/Temple Mount is special not only because of its location, but also because of its religious significance for Jewish, Muslim, and Christian.

According to Jewish tradition, the site of the Haram/Temple Mount is the location where both the First and Second Temples once stood. Although there is no archaeological evidence for the First Temple, the biblical book of Kings in the Hebrew Bible contains a detailed account of its construction and destruction. According to the Book of First Kings, the Israelite king Solomon built the First Temple in Jerusalem around 960 BCE. Chapters 6-7 describe the measurements and decorations for the temple that Solomon built and state that the building was constructed to house the Israelite godYahweh. As a result, the temple came to mark the center of religious devotion in ancientIsrael. According to the biblical account, the First Temple took 7 years to finish where every detail in the temple was built according to the word of the godYahweh. The furnishings inside were all well designed: pure gold overlaid the inside of the sanctuary, bronze pillars and capitals set in the shape of lilies, the sea made by mental resting right on twelve bulls facing every direction, and golden altar, table, lamp, even basin (1 Kings 7: 49-50). The ark was sent into the sanctuary of the temple and Lord kept his promise to put Solomon in control of Israel. People's dedication to God are also shown and served around the temple with sacrifices and festivals (1 Kings 8: 2).

However, according to the Book of Second Kings, the king of Babylon invaded the land of Israel and destroyed the temple in $586 \mathrm{BCE}$. When the Babylonians removed all the treasures from the temple of Yahweh, they set the structure on fire. (2 Kings 25, v. 9). People who remained in the city were carried into exile along with deserted people (v. 11). The Babylonians broke down the bronze pillars and other bronze treasures of the temple and carried them back to their capital at Babylon (v. 16).

In 515 BC, about 70 years after the Babylonian destruction of the First Temple, Cyrus the Great of Persia defeated Babylon and encouraged the Israelites go home and rebuild the temple. The main sources for our knowledge of this event come from Persian and Jewish historical sources. One of the most important sources is the so-called Cyrus Cylinder, which is a cuneiform text that describe King Cyrus liberating all the peoples whom the Babylonians had exiled. We also have Jewish sources in the Hebrew Bible that refer to King Cyrus as the one who gave permission for the exiles from Jerusalem to return to their holy city. According to these biblical sources, Cyrus allowed the Jews to rebuild the temple because he was told by God that the temple should be rebuilt. The temple building was of hewn stone and reinforced with wooden beams. The sanctuary this time was empty, however, because there was no Ark of the Covenant or Cherubim. The SecondTemple stood for nearly 600 years before the destruction of the temple and the exile of the Jews 70 CE by the Roman Empire. This event is commemorated in the Jewish calendar every year on the $9^{\text {th }}$ of Av when Jewish communities mourn the destruction of the First and Second Temples.

Today, this location is considered by some Jewish communities as the location of a prophesied third temple which is yet to be built, but is meant to be an anticipated place to worship. The consensus among Jewish scholars, however, is that since the location of the most sacred part is unknown, Jews should not walk on the Haram/Temple Mount to protect its sanctity.

Finally, the Temple Mount or Haram esh-Sharif is also believed to be the place where Abraham was commanded to sacrifice his son. This story is found in the Torah but is also alluded to in later Islamic tradition. According to the Book of Genesis in the Torah, Abraham was told by God to sacrifice his only son as a burnt offering on the mountain in Moriah (22:2). Abraham brought enough wood, two servants, and his son Isaac and reached the place where God told him to go (v. 4). As Abraham built an altar, placed the wood, and prepared to slay his son, suddenly, the angel of the Lord stopped him (v. 10). The angel said since he hadn't withheld his son to God, he will be blessed with numerous descendants who will hold great possessions. A ram is then provided to be sacrificed by Abraham (v. 13). Traditionally, Judaism has located this story in the Torah at the same site of the building of the First and Second Temples. This tradition comes from the Book of Chronicles, "Solomon began to build the house of the LORD in Jerusalem on Mount Moriah, where the LORD had appeared to his father David, at the place that David had designated, on the threshing floor of Ornan the Jebusite" (3:2). Importantly, this text connects explicitly the Temples with the site of Mount Moriah where Abraham was going to sacrifice Isaac. 
The Temple Mount is known as Haramesh-sharif to the Muslims which means the Noble Sanctuary. The al-Aqsa Mosque inside the Haram/Temple Mount is considered to be the third holiest site in Islam, after the al-Haram Mosque in Mecca, and al-Nabawi Mosque in Medina.The Haram/Temple Mount sets up significant aspirations and universal symbols for Palestinians. These religious significance of the Al-Aqsa Mosque can be traced back to passages in the Qur'an. Muhammad's interactions with the Haram ash-sharif are documented in passages which indicated that Haram ashsharif plays a crucial role in Palestinians' religious world.

From Surah 17 in the Qur'an, the night journey of Muhammad was depicted as a phenomenal experience where Muhammad traveled "from the sacred place of worship (al-masjidal-haräm) to the furthest place of worship (al-masjidal-aqșa)" (Q17:1) on a white beast in one night. "whose surroundings We have blessed, to show him some of Our signs"(Q17:1) indicated this journey was more of a spiritual one which Muhammad was following Allah's calling. When Muhammad the arrived at the Al-Aqsa Mosque, he Started to pray and was led by the angel to the Dome of the Rock. It is believed that Muhammad's journey is the sign to bring prayers and blessings to Al- Aqsa Mosque and to turn this place into a blessed space and sanctuary.

The Dome of the Rock is known as the place where Muhammad embraced his ascension to heaven. According to Surah 53, "[The Prophet's] own heart did not distort what he saw"(Q53:11), meaning Muhammad reached the portal to heaven where his spirit and soul leaved his flesh to embrace glory. As he reached a higher horizon every time, he saw incredible sights and angels, met numerous past prophets. At the end, he reached into the divine presence and found the ultimate gift and heaven. The Dome of the Rock is considered the place of ascension to heaven, it is the ultimate goal and gift to all Muslims and is worth all appreciations.

\section{CONCLUSION}

The Second Intifada is aroused by the accumulation of suppression and inequality. As Sharon stepped on the holy sanctuary, all the hatred of Palestinians that gathered for years burstedinto actions to reclaim rights. Both sides were blinded by insanity that caused disruption to innocent ones.

When people were accusing leaders from both sides to take the blame, it is more significant to understand the conflicts between the Israel and Palestine in the long run which are the mainly reason for the Intifada. The continued occupation in the West Bank had sabotagedPalestinians' livelihood, while Israeli settlements broughtexpansionthat further broke Palestinian land into fragment. With Israeli control of the borders, economy in the West Bank for Palestinians was heavily damaged. In addition, Jerusalem, the sanctuary for Palestinians was also taken down that teared down their faith. As Palestinians put hopes on international helps, they ended in despair that the situation did not changed a bit. With all these reasons, the broke out for the intifada can be explain as the awaking of spirit for the nation.

This paper demonstrates the cause of the second intifada not only from both present and the past, but also through multiple perspective. Most people acquire information from the international perspective toward the Second Intifada, but it is also important to gain insights from both Israel and Palestine views, The Intifada may see to be only around the conflicts of two nations, but this paper also explain how the intifada fill in the picture globally. This paper can enrich your understanding of the intifada with different reasons but all critical, for instance, religion plays a vital role in the conflict around Jerusalem. Jerusalem is not only in the middle of the map between the two nations, but it religious purpose, meaning, and value surpass its location and lies in everyone's heart.

\section{WORKS CITED}

[1] Pressman, Jeremy. "View of The Second Intifada: Background and Causes of the Israeli-Palestinian Conflict: Journal of Conflict Studies." View of The Second Intifada: Background and Causes of the IsraeliPalestinian Conflict | Journal of Conflict Studies, 2003, journals.lib.unb.ca/index.php/jcs/article/view/ 220/378.

[2] Edited by JadIssac, 40 Years of Israeli Occupation, www.arij.org/atlas40/index.html.

[3] Wilson, Leah. "Boycotts to Bombs: History, Causes, and Comparison of the Palestinian Intifadas." 2014, https://uknowledge.uky.edu/cgi/viewcontent.cgi?article=1014\&context=honprog

[4] “The Temple Mount / Al-Haram Al-Sharif.” Institute for Global Change, 2014,

[5] institute.global/policy/temple-mount-al-haram-al-sharif. [...] 
[6] “Why Is The Temple Mount So Important.” Moriah Stone Jewelry Collection, 11 Feb. 2019, www.moriahcollection.com/temple-mount/. [...]

[7] MJL. "What Is the Temple Mount?" My Jewish Learning, www.myjewishlearning.com/article/what-is-thetemple-mount/.

[8] Yemma, John. "Jerusalem's Dome of the Rock: Jewish, Muslim, or Christian?" The Christian Science Monitor, The Christian Science Monitor, 11 May 1982, www.csmonitor.com/1982/0511/051163.html.

[9] Bard, Mitchell. "U.N. Security Council: The Meaning of Resolution 242." The Meaning of UN Security Council Resolution 242, www.jewishvirtuallibrary.org/the-meaning-of-un-security-council-resolution242.

[10] Database, ECF. United Nations Security Council Resolution 242 (1967), ecf.org.il/issues/issue/121unsecurity-council-resolution-242.

[11] History.com Editors. "Oslo Accords." History.com, A\&E Television Networks, 16 Feb. 2018, www.history.com/topics/middle-east/oslo-accords.

[12] BBC. "BBC NEWS.” BBC News, BBC, news.bbc.co.uk/2/shared/spl/hi/middle_east/03/v3_israel_ palestinians/maps/html/1967_and_now.stm.

[13] Sontag, Deborah. “AND YET SO FAR: A Special Report.; Quest for Mideast Peace: How and Why It Failed." The New York Times, The New York Times, 26 July 2001, www.nytimes.com/2001/07/26/ world/and-yet-so-far-a-special-report-quest-for-mideast-peace-how-and-why-it-failed.html.

[14] “The Separation Barrier.” B'Tselem, 2017, www.btselem.org/separation_barrier. [...]

[15] "Al-Aqsa Intifada: Background \& Overview." Background \& Overview of Al-Aqsa Intifada, www.jewishvirtuallibrary.org/background-and-overview-of-al-aqsa-intifada. [...]

[16] Harms, Gregory, and Todd M. Ferry. Palestine-Israel Conflict: A Basic Introduction. Pluto Press, 2008.

[17] Bunton, Martin. The Palestine-Israel Conflict: A Very Short Introduction. Oxford University Press, 2013.

Citation: Lin, Pengzhe. "The Israeli-Palestinian Conflict and International Relations" International Journal of Humanities Social Sciences and Education (IJHSSE), vol 8, no. 4, 2021, pp. 132-138. doi: https://doi.org/10.20431/2349-0381.0804011.

Copyright: (c) 2021 Authors. This is an open-access article distributed under the terms of the Creative Commons Attribution License, which permits unrestricted use, distribution, and reproduction in any medium, provided the original author and source are credited. 